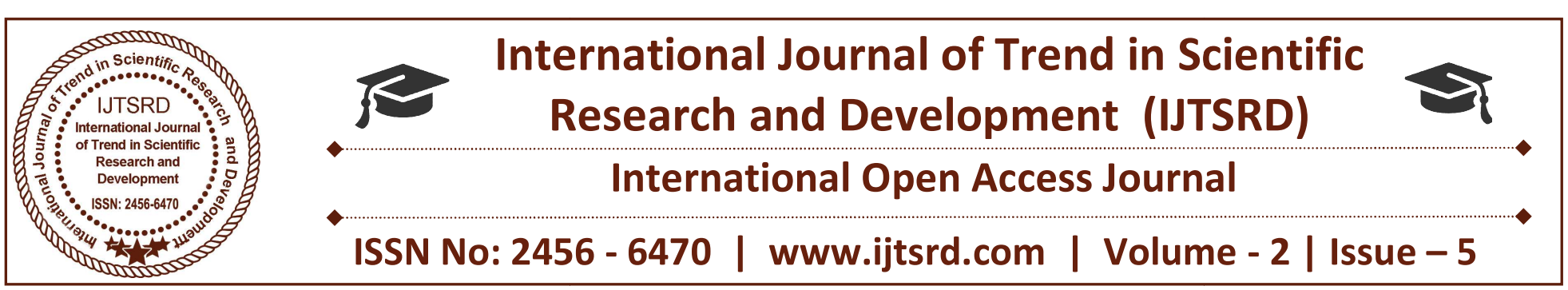

\title{
Knowledge, Belief \& Perspective on Men's Rights Activism of General Male Population
}

\author{
Shailja Soni \\ B.B.A., L.L.B. (Hons.), Indore Institute of Law, \\ Indore, Madhya Pradesh, India
}

\begin{abstract}
Even after years of freedom, no individual is free altogether. The society imposes multitude of restrictive "shoulds" on its members, both legally and socially. These "shoulds" have been developed as a way of living over a long period of time. They define the roles, especially social roles like- husband, wife, parent, child, employee or neighbor. This has been the practice of society to define gender roles and to expect particular or different kinds of behavior from the males and females occupying these roles. We have usually heard about sex stereotyping which has limited the potential of women and in turn gave rise to the women's movement. But now-a-days, men are becoming aware about their limiting roles which they are expected to full fill as per the society's expectations. Men are facing injustice under the facing injustice under the family law. The laws are framed favouring women. The society has stereotyped the role of a man, for example, a real man is strong, competitive, sexually, competent and silent suffering. A man is dependent on women for a number of reasons. It is established that a woman is needed for child rearing, health maintenance, housekeeping and cooking. This has limited the role of a man as a privilege or burden as the case may be. There is a view which is accepted by some people of both the sexes that the stereotypical behavior of men has resulted in the oppression of women and therefore it must change. The changes in the society have provided men with an excellent opportunity to redefine options for men. It is appropriate for men to play an active role and be part of an initiative to promote gender neutral laws which would make a society a better place to be.
\end{abstract}

\section{INTRODUCTION}

The men's rights movement (MRM) had been initiated in the early 1970s. it took its color from the men's liberation movement. The men's rights movement consists of a variety of groups and individuals who share their concern on numerous social issues which includes family laws, child custody, sexual harassment, domestic violence. In all the above specified cases, the laws are female favored. Some of the intellectuals think that the men's rights movement has been initiated as a response to the feminist movement. Now it is an old myth that men possess greater power or advantage than women. A number of scholars argue that feminism has gone too far that it is hindering the rights of men. While other scholars argue that the men's right movement is misogynistic in nature.

Various nonprofit organizations in India are working for the awareness about men's rights activism. This movement is not misogynistic in nature as it proposes gender neutral laws and repeal the laws which are somehow biased against men.

There are a number of concerns which need to be addressed that note bias against men in India. These activists claim that anti-dowry laws in India are used to harass and extort money from their husbands' which attributes to the high suicide rate among married men in India. The divorce and child custody laws are also biased against men. The rape reporting laws and sexual harassment law are also unfair.

\section{HISTORY OF MEN'S RIGHTS MOVEMENT}

The men's rights movement in India was started by Mr. Ram Prakash Chugh after having faced false 
claims of dowry harassment himself. He formed an organization called "society for prevention of cruelty to husbands". A helpline named Sangyabaly was started for husbands and families harassed by antidowry laws by Arun Murthy in Bangalore. On $19^{\text {th }}$ November 2007, International Men's Day was celebrated for the first time in India by "Save India Family Foundation", (SIFF).

\section{CONCERNS AND DISCUSSION}

\section{Anti-Dowry Laws}

The anti-dowry laws are being frequently used to harass and extort husbands. The suicide rate among married men has also increased over the years. Dowry was criminalized in the year 1961 under the Dowry Prohibition Act, 1961. The most debated and popular section i.e. Section 498A of the Indian Penal Code was introduced in 1983.

The Section 498A of the Indian Penal Code states that:

Whoever, being the husband or the relative of the husband of a woman, subjects such woman to cruelty shall be punished with imprisonment for a term which may extend to three years and shall also be liable to fine.

\section{Divorce and Child Custody Laws}

The divorce and child custody laws are biased against men. Men are not allowed to see their children for a long period of time after divorce. Men's rights activists advocate that wife should not be granted alimony if she is the primary earner of the family. The law must also see men capable of bringing up children. In India, the custody of children after divorce is governed by two laws: Guardians and Wards Act, 1890 and Hindu Minority and Guardianship Act, 1956. The irony is that both these laws do not contain provisions for shared parenting or joint custody.

\section{Domestic Violence}

The number of men who are victims of domestic violence has increased in the recent years. But such cases go unreported as men feel ashamed to report the abuse. They also fear false accusations against them in reprisal. Some groups like the Save Indian Family Foundation (SIFF) and the Indian Social Awareness and Activism Forum (INSAAF) have demanded inclusion of issues faced by men in the National Family Health Survey (NFHS) conducted by the
Ministry of Health and Family Welfare to manifest the actual picture of the situation.

The Protection of Women from Domestic Violence Act, 2005 provides protection to wives and female live-in partners from domestic violence carried out by husbands, male live-in partners or their relatives. Swarup Sarkar of Save Family Foundation has termed the law as legal terrorism.

\section{Rape Reporting Laws}

The number of reported rape cases rose from 16,075 to 24,923 between 2001 and 2012. At the same time, the conviction rate fell from 40.8 percent to 24.2 percent. Some men's rights activists believe that the low conviction rate is because of false reporting of cases.

\section{Suicide}

The Save Indian Family Foundation (SIFF) has claimed that the suicide rate of married men is twice as that of married men is twice as that woman because they are unable to withstand the abuse from their wives. It has pointed to the National Crime Records Bureau (NCRB) data to show that the suicide rate in married men is much higher than that in married women. A researcher at the Save Indian Family Foundation found out that police don't take any action even if the suicide note of man states that he was tortured by his wife and in-laws, but in the case of women the husband's family is taken into custody without investigation.

\section{Sexual Harassment Laws}

The Sexual Harassment of Women at Workplace (Prevention, Prohibition and Redressal) Act, 2013 is not a gender-neutral law. The bill was originally gender neutral until Ministry of Women and Child Development and some NGOs intervened and changed the name. It is an outdated concept to consider that only women suffer from sexual harassment.

\section{THE STUDY AND JUSTIFICATION OF STUDY}

A research was conducted by the author of this research paper under All India Institute of Local Self Government in the city of Indore to get the insights of men on this issue. It was a brief review regarding men's rights related beliefs among the men in the society which reveals that the statutes related to domestic violence and sexual harassment must be made gender neutral. 


\section{RESEARCH METHODOLOGY}

\section{OBJECTIVES:}

$>$ To define the awareness level and knowledge about various acts (the Domestic Violence Act, 2005, the Sexual Harassment of Women at Workplace, 2013, the Dowry Prohibition Act, 1961, the Pre-Conception and Pre-Natal Diagnostic Techniques Act, 1994) in general. Male population of Indore city.

$>$ To find out the perspective of male population about having gender neutral laws.

$>$ To evaluate the respondent's belief towards false filing of cases by women in family matters.

\section{HYPOTHESIS DEVELOPMENT}

A hypothesis is a proposition, which the researcher wants to verify. In this research there are some hypotheses which are given below: -

$>$ There is a relationship between educational qualification and want of gender neutral laws related to domestic violence by the respondents.

$>$ There is a relationship between the marital status and having witnessed male victim of domestic violence.

\section{RESEARCH DESIGN}

As this research is under taken to know different perspectives of male population regarding 'Men's Rights' by means of structured instrument ie. "Questionnaire". So, here descriptive research design is used for research.

\section{DATA COLLECTION TECHNIQUES}

$>$ PRIMARY DATA- Through schedules as the aim and objective of the study had to be cleared to the respondents and remove the difficulties of any respondent in the understanding concepts.

$>$ SECONDARY DATA- It was collected from interest as well as journals and newspapers.

\section{SAMPLE DESIGN AND SAMPLE SIZE}

$>$ UNIVERSE: The whole urban area of Indore city is the universe for this research.

$>$ SAMPLE SIZE: Total sample size is 100 males.

$>$ SAMPLE UNIT: Unit of analysis is a male above 18 years of age.

> SAMPLE DESIGN: Stratified random sampling.

\section{DATA COLLECTION}

Having prepared the questionnaire and selected the sample design and the size of sample, the next step is to organize and conduct the field survey. So, we have selected these fields for study. For data collection, we have explored Vijay Nagar, Palasia, Sarafa, Ushaganj, Malharganj and Kalani Nagar areas of Indore city. We have collected the data by interviewing and scheduling the respondents.

\section{HYPOTHESIS}

The hypothesis testing was done by using the ChiSquare Test.

In the first hypothesis, after observing the frequency of men's educational qualification and want of gender neutral laws, it was found that there is no relationship between educational qualification and want of gender neutral laws related to domestic violence by the respondents.

In the second hypothesis, after observing the frequency of the marital status of respondents and having witnessed a male victim of domestic violence, it was found that there is a relationship between the marital status and having witnessed male victim of domestic violence.

\section{RECOMMENDATIONS}

1. We have seen that there is an association between the marital status and having witnessed a male victim of domestic violence. As $59 \%$ of the population is married so we can infer that most of the married men who admitted having witnessed a male victim of domestic violence are actually a victim to the issue.

2. There is a need to aware people about the formation of committees to monitor sexual harassment at workplace for women as $35 \%$ of the population is engaged in service sector and 20\% of them do not have any amendment regarding the protection of men must be introduced.

3. The main reason behind any misunderstanding between a married couple is ego. Therefore, egotistical issues must be addressed by mutual understanding or couple counselling.

4. Most of the respondents believe that men do not have the same rights as women in relation to domestic violence, sexual harassment at 
workplace and child custody. There is a need to address these issues.

5. Dowry is still practiced in our society. And still about $31 \%$ of the respondents didn't know about the Pre-Conception and Pre-Natal Diagnostic Techniques Act, 1994.Awareness about the Dowry Prohibition Act, 1961 and PCPNDT Act, 1994 must be spread. Pamphlets, posters, newspapers and other publications serve as practical media for sharing basic legal information with audiences of various sizes and literacy levels. Some materials of this kind provide specific advice, while others seek to promote broader attitudinal change.

6. Challenging norms and behaviors is thus a collective challenge for men. It is also a challenge for women, who consciously or unconsciously often perpetuate these same social norms in the way they raise their sons or interact with men.

7. We must promote awareness of how gender-based expectations limit men legally, socially and psychologically.

\section{CONCLUSION}

As UN Secretary General Kofi Annan has stated, "Gender equality is more than a goal in itself. It is a precondition for meeting the challenge of reducing poverty, promoting sustainable development and building good governance”.

This recognition is missing in our country. Transforming the prevalent social discrimination against women became top priority, and it must happen simultaneously with increased direct action to balance power among both the genders.

We must empower men but of course not in the conventional way by giving them more power over women. Both women and men are an integral part of the gender system.

In this research we have seen a lot of gender biased laws which need to be taken care of. Most gender initiatives continue to focus on women. This is understandable. But the balance of power must be given due consideration.

Whenever we talk about women, we never think of it as being anti-men. If we talk about men, it should not be considered as anti-women.

\section{REFERENCES}

Books and Projects

1. Sexual Politics by Richard Dumphy

2. Need for Men's Rights- Amit Deshpandey| TEDx Juhu

\section{Websites}

1. ncfm.org

2. Www.huffingtonpost.com

3. www.telegraphindia.com

4. www.thegaurdian.com

5. www.dailymail.co.uk

6. www.indianexpress.com

7. www.hindustantimes.com

8. www.deccanchronicle.com

\section{n}

$\cos$
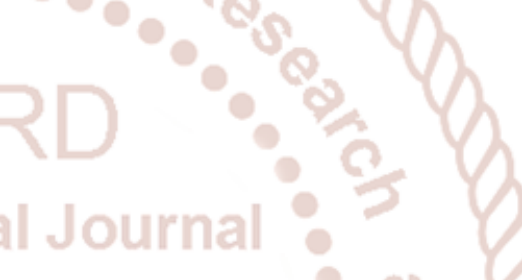